\title{
A Need for Theorizing Corporation: An Accounting Perspective
}

\author{
Al-Adeem KR* \\ King Saud University, Riyadh, Saudi Arabia
}

\begin{abstract}
While the precise moment when accounting was first used remains unknown, one can speculate that the emerging need for economic systems necessitated the invention of technologies such as double-entry bookkeeping and the creation of new business models to determine the purpose of accounting at a given time period. Corporations as a business model may not be served by the conventional role of accounting, which caters to the needs of engaging in other businesses forms. Accounting principles such as a historical cost valuation basis can only be justified in reference to accounting rules but not necessarily theories. A corporation needs to be theorized and properly conceptualized from an accounting perspective so that the role of corporate accounting may be suggested or an existing one adopted.
\end{abstract}

Keywords: Accounting roles; Corporation; Historical cost

\section{Introduction}

Accounting practice has emerged without a theory guiding its development $[1,2]$. By quantifying humans and entities' commercial activities and measuring the economic effects of such activities, accounting has pragmatically responded to the needs of businesses and societies. Accounting practices evolved as a reaction to real problems [3]. Such an emergence may have affected the manner in which some early accounting writers viewed accounting. Vatter, for instance, contends that "the process of accounting is primarily narrative and analytical process" [4]. However, as societies continue advancing and progressing and new forms of businesses are being invented and introduced, accounting can "no longer be regarded as a mere collection of techniques...” [5].

Theorizing and conceptualizing practiced accounting has become an urgent need since the emergence of "investors" as a segment of society [6]. Such a segment has a political weight causing governments to react when their capital markets display failures. The US government's recent action "represented by the Sarbanes-Oxley Act, to ensure confidence in the capital market" is only an example of governments' care to investors [7]. If the accounting profession does not serve them well, then governments act. The divorce between ownership and management contributes to the existence of members in society who own but do not control their invested wealth in a corporation. The attempt to serve two "masters" in a corporation, that is, shareholders and other stakeholders, remains a challenge in accounting [8]. Shareholders contribute a portion of their wealth and savings to create giant corporations. Following the creation of publicly held corporations, the task of accounting, specifically financial accounting, is to inform these shareholders. Property rights entitle shareholders the right to be aware of their invested wealth [9]. A way to communicate to them information on their investment interments, for example, their property in corporations, is through financial statements and reports that best address the needs of passive owners and finance-illiterate investors. Accounting theorists, academic accounting organizations, and professional accounting bodies vary in their position on a suitable approach to decide upon the content presented in such statements and reports. While some accounting theorists, for example, Sanders et al. [10] believe that theorization in accounting should be directed toward describing practiced accounting, others, such as Paton and Littleton, prescribe how accounting should be practiced [11].

Practiced accounting cannot be entirely rationalized in theory. This especially holds true for corporate accounting as practiced accounting emerged in response to the needs of sole and partnership businesses. Contemporary corporate accounting is justifiable mostly in reference to accounting rules [12-14]. Double-entry bookkeeping is taken as an act of rule, not a theorized concept [15]. Rules cannot be integrated to form a theory [15] and some other practiced accounting techniques may not be theory-driven procedures [16]. For example, despite historical cost being an accounting principle prescribed in the conceptual framework of the Financial Accounting Standards Board (FASB) as a basis for valuation, the use of fair value to record and report information is progressing in accounting entities in the finance sector [17].

In this paper it is argued that historical cost does not meet the need of active investors, mainly institutions, to predict the prospects of a corporation in which they invest their wealth and savings. Basically, one cannot predict the outlook of a corporation in which his/her wealth is invested by looking backward. Historical cost valuations have been imposed by regulatory authorities given the passiveness of individual investors in today's corporate world. Charging the stewardship of executive management, a role assigned in corporations, with obligations and owners' invested resources and assets can be verified when assets are recoded at their neutral and objective acquisition cost. Thus, "an objective of financial statements is to report on the control and use of resources by those accountable for their control and use to those to whom they are accountable" [18].

This study can be viewed as responses to the call for understanding accounting itself and its internal logic. Burchell et al. [5] assert that “... although there has been an enormous investment of effort in improving the accounting craft and even charting its technical development, very few attempts have been made to probe into the rationales for the existence and development of accounting itself."

The remainder of this paper is organized as follows. Section 2 discusses accounting adaptability by illustrating the role of accounting

*Corresponding author: Al-Adeem KR, King Saud University, Riyadh, Saudi Arabia, Tel: 966540518179; E-mail: kra3@case.edu

Received April 12, 2017; Accepted July 18, 2017; Published July 28, 2017

Citation: Al-Adeem KR (2017) A Need for Theorizing Corporation: An Accounting Perspective. Int J Account Res 5: 166. doi:10.4172/2472-114X.1000166

Copyright: $\odot 2017$ Al-Adeem KR. This is an open-access article distributed under the terms of the Creative Commons Attribution License, which permits unrestricted use, distribution, and reproduction in any medium, provided the original author and source are credited. 
in three forms of business, followed by a discussion on how corporations have posed as a challenge in accounting since their introduction as a business form in section 3 . In section 4 , the general impossibility of modern accounting in capturing the economic reality of a corporation is discussed. After urging further research on the significance of theorizing corporations or firms, I conclude that accounting has retained its usefulness in society through its adaptability to new purposes and roles.

\section{Determining the purpose of accounting: adaptability}

The precise moment when accounting was first used remains largely unknown. Nevertheless, one can speculate that the emerging needs of economic systems necessitated the creation of new business models that determine the purpose of accounting. In other words, the "roles which accounting serves in organizations are created, shaped and changed by the pressures of organizational life" [5].

Double-entry itself was a response to business needs. Yamey asserts that, "double-entry developed in direct response to some particular business needs, which was not adequately served by earlier methods of accounting" [19]. According to Pacioli, double-entry bookkeeping is "nothing else than the expression in writing of the arrangement of a merchant's affairs" [20]. Over the years, merchants and entrepreneurs have felt the need to hold people accountable. Hackett and Mobley stress that "As soon as the first entrepreneurs contrived a method for making a profit, they contrived ways of controlling and protecting that profit" [21]. As per Chatfield "bookkeeping faced the problem of holding people accountable in societies where vast majority were illiterate" [22]. Yamey further explains that owners' delegated authority in managing their wealth to agents "played a significant part in the emergence of double-entry" [19]. That is, "agents had to keep accounts to show their indebtedness to their principals; that these accounts assumed a distinctive form; and, that double-entry is a lineal descendant of that system." Double-entry bookkeeping also assists owners in calculating income by revolutionizing artificial accounts and integrating them with real ones to visibly express "the interrelation of capital in use and the income which results from managements' supervision of that use" [23]. Such a unique integration between nominal and real accounts is a technological accounting innovation.

Similar to the invention of doubled-entry bookkeeping in response to business needs, accounting is a response to organizational needs in societies $[5,24]$ asserts:

Accounting originated in known circumstances in response to known needs; it has evolved and grown in harmony with its surrounding; its changes can be explained in terms of forces current at the time. Truly, then, accounting is progressive and relative. It came from definite causes, it moves toward a definite destiny.

In a similar vein, Anderson argues that "accounting is a creation of society and operates within the parameters established by society and economic circumstances...it reacts and adjusts to changes in its environment as well as to changes in its constituents" [25]. Yamey states "accounting resembles crafts in so far as it consists of techniques designed to serve certain practical ends. The methods and instruments of crafts generally undergo a continual though often almost imperceptible process of change" [19]. To this effect, Wyhe adds that "accounting must change with the times. It must become responsible, purposeful, and flexible" because "the business environment in which accounting exists is changing rapidly and even dramatically" [26].

In the context of commerce, money, cash equivalent, and appreciated goods as well as commodities are considered to compose the concept. Even in a simple business form, money is received and paid. These valuable items need to be safeguarded and accounted for; otherwise, wealth would be subject to theft and misuse. The key objective underlying accounting is to help a business owner control business resources. As DR Scott puts it, "the decline of control in economic markets required reassessment of the growing importance and role of accounting information in economic activity" [16].

Irrespective of the form of businesses, that is, sole companies, partnerships, or corporations, accounting is obligated to serve its master, who provides capital and wealth to the creation of the entity. One can thus, identify the purpose of accounting in the context of a given time period by examining capital supplier needs. Accounting does not have a single purpose through which capital contributors have been served over time. According to Chatfield, "There seem to be certain perennial demands which every developed society makes on its accounting records" [22].

Individual and family owned businesses: An old and less complex form of conducting business is a sole company. Before partnerships and joint ventures came into existence, family owned businesses were a popular, or even the only, form of conducting business. To date, sole companies are considered the only model when efforts cannot be joined to run a family business. In fact, some nations are yet to experience participation in a capital market. Thus, ignoring sole companies as a form of business paints an incomplete picture and thus, limits our knowledge of the purpose of accounting.

The integration of ownership and control, as phrased by Lazonik, characterizes this model of conducting business [27]. An owner is generally aware of daily transactions and to be well served by accounting, he/she needs to be supplied with useful (financial and nonfinancial) information on business operations to account for resources and hold accountable those trusted to execute tasks. Thus, in such a business model, controlling resources becomes a suitable accounting purpose.

Partnerships and joint ventures: Italy, particularly Venice, experienced economic developments through trade expansion that extended to overseas commerce. Hendriksen and Breda state that "silks, spices, and dyestuffs flowed into Europe; salt, timber, grain, and wool flowed out [28]. Merchants in parts like Genoa, Amalfi and Venice grew rich on the trade." The economic scale of trade was so huge that sole companies were unable to provide the required capital and many individuals chose to evade the high risks. The trade volume and high risk necessitated the formation of partnerships as a business model, in which individuals pool their capital and collaborate to create bigger businesses compared to the previous sole model. In their description of the state in Italy, Hendriksen and Breda [28] reported: As trade expanded and wealth accumulated, individual trading was replaced largely by trading through agencies and partnerships. The use of partnerships permitted the risks of the long sea voyages to be shared and allowed the wealth of the capitalist to be combined with the daring of younger traders.

Baskin and Miranti add, "silent partnerships were common for local business and thus easily accessible principals who could deriving monitor their performance. Sedentary partners often hired active agents to conduct overseas trade" [29].

A key characteristic of conducting business through partnerships is trust, which somewhat compensates for the risks in commerce. Put differently, "with risky equity particularly with respect to the action of 
agents, such risks were offset by the deep personal loyalties of covenants deriving from kinship bonds" [29].

The formation of partnerships influenced accounting by giving a firm an entity that was separate from its owners [28]. In this form of business, ownership and control are not independent of each other, although ownership is divided between partners. In their study on the verbal usage of "fair," "correct," and "true," Chambers and Wolnizer include "relevant clauses of partnership agreements" and find "true accounts" to be maintained, implying that partners were able to understand and communicate data in different measurements and were present to guard their investments [30]. Because partners' knowledge was up to date and they were aware of day-to-day operations, the classical purpose of resource control was suitable to the needs of partners in partnerships and joint ventures and thus, accounting was not required to adapt to a new purpose. Furthermore, given that business owners in the past interacted with their businesses, they were not required to produce financial statements. Pacialo's omission of financial statements in his description of accounting practices by merchants in Venice at his time was not random [31]. Littleton elucidates "proprietors were in personal contact with their affairs and the occasional computation of a Profit and Loss account in the ledger was ample for their needs" [31].

Corporations: The industrial revolution in the West called for a large-scale business model that was capable of efficiently running a new form of economy; in particular, efficiency became a key requirement to run the new Western economy [32]. The old business model, partnerships and joint ventures, could no longer supply the demanded capital to construct plantations and required constructions accompanied by the industrialized economy. Because of their scale and ability to magnetize capital, corporations have become the predominantly recognized business model since the twentieth century. Corporations have played a critical role in modern economies: take for example the impact of canals and railroads on the American economy in the early twentieth century. As Previts and Merino [33] put it, Corporations arose because of their capacity to support expanding markets and enterprise operations at levels of competitive efficiency called for in a nation where the tasks and risks were large and the sources of wealth and capital not highly concentrated. There was also the need to use scarce skills, both technical and managerial, wisely. The high costs of scare labor encouraged use of machinery and therefore begat relatively larger investment outlays. The appetite of such operations for capital would influence the shape of the money markets and the industrial revolution that overtook the American economy in coming decades.

Survival in an industry is conditioned by an organization's ability to "deliver demanded products by costumers at the lowest price while covering costs" [34]. In the early days, accountants made better efficiency experts than the others [35]. "Standard cost accounting, industrial budgeting and operation planning, controllerships, research analysis techniques and methods" evolved as accounting technologies to facilitate managerial focus on the "competitive significance" of low unit costs [36]. Moreover, today, the concept of efficiency has further advanced. The desire to seek a higher order of economic efficiency has led to the increased centralization and integration of financial and related information systems in even larger-scale entities, creating multinational corporations [37]. Various industries have been experiencing consolidations since the 1950s [38]. In the late 1980s, the audit market reacted with waves of consolidation that left the market with Five Big Firms, now four after the dissolving of Arthur Anderson, instead of eight. Building "bigger practices that will provide more services to the clients" motivated the consolidation of audit firms [39].
With corporations emerging and being acknowledged as the optimal and preferred form of conducting business, accounting was expected to provide economic information to users about resources owned by their corporations and related obligations. In modern organizations, "accounting rose to mediate between divergent interests in an organized endeavor, to legitimize and justify particular stances and, above all, to create a symbolic structure within which action could be achieved" [5]. According to the Statement on Accounting Theory and Theory Acceptance, "accounting writers appear to agree that the central purpose of financial accounting is the systematic provision of economic data about reporting entities [40]. The data are provided to individuals and groups external to the reporting entity." DR Scott concludes, "Accounting was a means of mediating conflicts of interest in business and providing justice" [16].

In sum, analysing the contexts in which accounting operates allows us to observe "the diversity of functions which can be associated with even a single accounting" [5]. Monitoring is a classical purpose of accounting associated with the owner's awareness of day-to-day operations. Historical cost was a suitable measurement basis for the owner to hold those who work for him/her accountable and control resources. "Since the agent is accountable to another for the disposal of the merchandise entrusted to his care" [19], "there would be no profit calculation, partly because the agent would not necessarily know all the relevant facts" [19]. When ownership and control are integrated, accounting is able to fruitfully function and adequately serve its master. In this way, no disappointment is directed toward accounting.

However, the separation of ownership and control gave rise to a legitimate question: how does the classical purpose of accounting meet the needs of capital market participants, particularly investors of present-day corporations? In 1936, A Statement of Objectives of the American Accounting Association recognized a shift in the purpose of accounting, which corresponds to the changes in the business model [41].

Accounting, originally designed for the purpose of providing internal control of business affairs by private owners, now finds itself faced with the responsibility of compiling and expressing the results of business operations in a way which will meet the needs of investors, governmental units, and the public at large, as well as those of the immediate management. The mechanism of private accounting must be adapted to serve these broad social and economic purposes (p. 1).

Accounting has been extended to promote "corporate accountability" and further "rational decision making" [5].

\section{Corporation: challenges confronting accounting}

A core feature of present-day corporations is the divorce between ownership and management [42]. By law, investors are owners of their corporations and their ownership cannot be questioned, as is reflected in proprietary theory in accounting [43]. Investors, generally, do not run their corporations and hence, are unaware of day-today transactions, which leave them at a disadvantage [29]. Baskin and Miranti further acknowledge the difficulties facing investors in evaluating managers' performance. As they put it, The small, atomistic firms that were the focus of classical microeconomics provide few insights into the functioning of oligopolistic corporations. Thus, it proved difficult to develop reliable measures to assist investors in evaluating the performance of companies of great scale and scope [29].

Evaluating the decisions of those who run corporations is different from managing what a person owns. It is also dissimilar from monitoring whom the person trusts and offers money for investment on the basis 
of personal relationships and ties. This leads to the recognition of the need of investors who want to evaluate corporations.

Investors, today, are more passive than those in the past. Discussing past investment activities and investors, Baskin and Miranti describe them as active investors of a "predominated pattern" [29]. In their study on the usage of the words "fair," "correct," and "true," Chambers and Wolnizer find that prior to the mid-nineteenth century, these words were used by corporations [30]. Investors in the past stood to safeguard their investment and thus, were able to understand different accounting measurements, for example, historical cost and fair value [44]. In addition, they were aware of their corporations' financial conditions and position. The classical purpose of accounting may still have been initially suitable to the needs of the corporate economy when investors were active. It was not until investors tended, chose, or were forced to be passive that accounting demonstrated the incapability of serving the needs of an economy, which can be best described by the separation between ownership and management.

The corporate economy poses a challenge to accounting [33]. It is questionable whether accounting credibility provides information that helps evaluate corporations. Baskin and Miranti state that "in the case of equity...valuation was more problematic because it depended on projection of the trend of future earnings available to pay dividends" [29]. Beaver et al. suggest the use of "predictive ability" as a criterion of useful information [40]. The SATTA clarifies that the authors do not recommend forecasting by accountants and states

While it is clearly recognized that forecasts are relevant...to decisions, there have been some who have argued that the very nature of the market makes it necessary for the risk-bearing decision maker, as opposed to the accountant, to prepare the forecasts [40].

Accounting historians such as Previts and Merino argue that accounting can still be representative of investors [33]:

In their seminal work, Adolph Berle and Gardiner Means claimed that separation of ownership and control had undercut the role of profits to "owners" as an efficient means of allocating economics resources [41]. The concept of "managerial capitalism" raised serious questions about the relevance of traditional accounting data. Accountants responded creatively and effectively to this new challenge. By the end of the decade, accounting theorists had developed a historic cost allocation model that effectively silenced questions about the relevance of accounting profit and reaffirmed the primarily of ownership rights.

However, the SATTA unveils a problem associated with accounting theorists' proposed solution of cost allocation techniques [40]. The inherently arbitrary procedures accompanying cost allocation can be a serious limitation and thus, damage the potential intended outcomes of allocation techniques, causing wide dissatisfaction and "vexing controversies" $[40,45]$.

\section{Possible unsuitableness of historical cost as an accounting valuation basis}

The 1934 Security Act gave the SEC the required authority to regulate corporate reporting in the United States [46,47]. When Garman G. Blough became the first SEC chief accountant, the SEC insists upon historical cost accounting so that financial statements do not contain "misleading disclosures"[48], which led to the FASB's adoption of the cost principle in its conceptual framework.

When the FASB's committee worked on the Statement of Financial Accounting Concept No. 5 (SFAC No. 5) [49], Recognition and
Measurement, SEC's response to the Accounting Principle Board's (APB) opinion on current value remained vivid in their minds [50]. To avert any confrontation with the SEC; assure the continuation of FASB, a then newly established body; and not jeopardize its life expectancy by repeating the mistakes made by the APB, the committee adopted historical cost and endorsed certain alternatives practiced in accounting. Professor Robert Sterling [51], a pioneer accounting theorist, describes the language used to draft SFAC No. 5, Recognition and Measurement, as "muddy" and "muddy language is productive of error" [49]. Zeff analyzed and revealed potential reasons underlying the FASB's position on historical cost and concluded the following [50].

The SEC's well-known antipathy toward departures from historical cost accounting in the financial statements might have been seen by some members of the board as an obstacle to a principled choice. Memories were still fresh of the condemnation by the APB (and by the SEC's chief accountant) of Sprouse and Moonitz's advocacy of current value accounting in their accounting research study published in 1962, resulting in the APB's decision to consign both the postulates and principles studies to oblivion. Some FASB members may not have wanted to risk having the board's conceptual framework similarly marginalized as "too radically different."

The preference of historical cost measurement was a compromise made by FASB's to retain the SFAC No. 5. Kirk [50] contends "as the choice of measurement attribute could not be disengaged from the income-reporting implications of unrealized holding gains and losses, this compromise was necessary for Statement 5 to survive." In addition, Zeff [50] adds David Mosso a member of the board from 1978 to 1987 who continued as a member of the board's senior staff until 1996, has said that this proposition "may sound like a weak endorsement but at the time it was extremely contentious and a major concession to the Board members who favored more market value accounting."

The key advantage of historical cost is verifiability. The values disclosed in the balance sheet are supported by documents enabling their verification and thus, adds some objectivity to the disclosed number. However, in the classical measurement model, objective recoded acquisition cost is arbitrarily allocated across periods, causing a decline in claimed objectivity. Given the role of stewardship in accounting and that of executives to safeguard owners' resources, historical cost seems reasonable sense. In a similar vein, if the role of accounting is to protect owners' resources, then reporting on an entity's outlook, that is, "forward accounting," as described by Kohler [52], will not be under the accounting radar as an objective. As an accounting function, reporting forward-looking information is different from agents' reporting of historical data on owners' resources.

In addition to the SEC, those who prepare financial statements have resisted changes in the current value measurement. Zeff asserts, "Few [preparers] would have possessed any knowledge of measurement attributes other than modified historical cost." In addition, Revsine proclaims "departures from historical cost accounting represented a potential threat not only to the preparer community but also to accounting practitioners" [50]. Zeff further articulates, "Practitioners may have feared that their expertise would become obsolete by the imposition of an unfamiliar system of accounting" [50]. This viewpoint also holds true in the case of accountants. Change management literature addresses resistance to new methods, where promoters and believers of the old way become enemies of new, innovated, or invented ones [52]. Another reason for accountants to resist "abandoning the historical cost income model may have come from the profession's desire to continue portraying accountants as objective reporters of fact" [33]. 
In short, opposition to proposed valuation bases that compete historical cost value measurements has constrained the FASB in endorsing the current valuation basis. Zeff concludes "resistance to change from preparers, practitioners, and the SEC, as well as within the board-coupled with an in-difference, at best, by users constituted a high barrier for the board to surmount" [50].

This discussion can be extended to investors, in particular, active and institutional investors, and whether their needs have been considered. Furthermore, it is essential to explore their interpretation of the two valuation measurement bases and whether historical cost valuation meets their needs [53]. For tax purposes, in the United States, accountants evaluating inventories and determining the cost of goods sold assume goods that are imported last are the first to be sold. Valuating sold goods using recent prices during inflation increases the cost of goods sold in the income statement and thus, reduces reported accounting net income and tax liability [54]. In the United States, different versions of LIFO have been suggested over the years. For example, next-in, first-out (NIFO) was proposed as a result of a Congress Relief provision during the Korean War [54]. Another version of LIFO is high-in, first-out (HIFO), which is a combination of "the use of the lower of cost or market in conjunction with LIFO" [54]. Corporations in the United States must issue a $10-\mathrm{K}$ in compliance with the SEC's requirements and at the same time, submit to the Internal Revenue Service (IRS) financial statements in which the valuation bases differ from those followed by the SEC. This is only tentatively understood and perceived by interested parties, including individuals within the corporation and from the IRS. Accounting can only serve those who can understand its outcomes and produce numbers and data, both quantitative and qualitative. In other words, there is a need for an accounting system that can serve more than one master at a time, which can be expensive to operate and demanding in terms of function. Since not all current investors fully understand both accounting measurement bases, regulatory authorities must choose one that can be verified and objectively proven and accept the inherent subjectivity in such measurement models.

Alhomaid reports a factual story on investors of the Saudi Public Transport Company (SAPTCO), Saudi Arabia [46]. The company bought a piece of land in the centre of Riyadh, the capital of Saudi Arabia, for SAR 10,000 (approximately US \$2,500). The continuous gains from the land holding itself were never recorded in the income statement. The value of the land was maintained as per cost price in the balance sheet. As a result, the net income did not fully reflect corporate performance and thus, the economic reality of the corporation. About 25 year later, the corporation sold the land for hundred times its original cost. Investors, who held the corporation's shares sold them prior to recognizing the realized gains in the income statement, did not get their shares from the unrealized gains. In other words, historical cost measurement prevented investors who sold their stocks from realizing the attached gains. Historical cost can be an irrelevant and unfair valuation basis. An accounting entity is not static; rather, it constantly interacts with the environment and its elements. "Life in modern organizations is a constant interplay between the activities that we need to carry on and the organizational accounts we need to give" [5]. According to Chambers, an entity's balance sheet should reflect such interactions [55].

It is not surprising that Professor William Paton's pragmatic nature led him to express disappointment toward his role in promoting the historical cost principle in corporate reporting. In his speech at a conference held in the University of Florida in 1970, the guest of honour, publicly announced his dismay in the monograph published in 1940 that he co-authored with Professor Ananias C. Littleton. In particular, Professor Paton regretted calling for the use of historical cost and wished for the monograph to be out of print.

The American Institute of Certified Public Accountants' (AICPA) Special Committee on Financial Reporting, also known as Jenkins' Committee and officially as Improving Business Reporting-A Customer Focus: Meeting the information needs of Investors and Creditors, recommends that corporate reporting contains information on the corporation's outlook [56,57]. Section 3 of the Committee's recommendation commends the disclosing of forward-looking information on the corporation. Apparently, Jenkins' Committee concluded that corporate investors demand forward-looking type of information. Following the Committee, in 2001, the Steering Committee Report: Business Reporting Research Project, issued a report titled Improving Business Reporting: Insights into Enhancing Voluntary Disclosures, which found room for the significant broadening of forward-looking information [58]. This raises the following questions. How does an investor view a corporation's future when the entity's financial statements present historical data? Simply put, how is a driver expected to safely steer the vehicle forward when he/she is looking in the rear view mirror? In the context of the present discussion, how will an accounting entity move forward if it keeps disclosing its history? Incorporating statistical techniques in accounting would have assisted in the prediction function of accounting and transformed accounting theory as opposed to overloading it with rules and principles governing the application of double-entry such as conservatism [59].

\section{On the general impossibility of contemporary accounting in capturing the economic reality of corporation}

Despite their intended objectives, accounting principles and procedures cannot measure the economic reality of a corporation. White et al. state that "the financial reporting system is not perfect. Economic events and accounting entries do not correspond precisely; they diverge across the dimensions of timing, recognition, and measurement" [60]. "Accounting is what it is made" [61]. The relationships between "accounting systems design and the implementations process" and the "realities of organizations and social life is" debatable [5]. FASB's Conceptual Framework, a rules-based accounting system, is a concert reality detached from accounting. The same applies to accounting principles and concept statements, including SFAC No. 5, that collectively construct the Conceptual Framework for financial accounting. Professor Gary Previts (personal communication) declares that Generally Accepted Accounting Principles (GAAP) is our "truth." Accounting as practiced after the existence of corporations can only be justified by reference to accounting rules. DR Scott observes, "Accounting theory grew up as a body of rules or principles governing the application of double-entry technique to the affairs of business enterprise" [58]. Similarly, Professor Robert Sterling asserts, according to Lee and Wolnizer [12]. From the public dissemination of doubleentry bookkeeping knowledge by clerics, teachers, and merchants of the 15th, 16th, and 17th centuries to accrual and allocation accounting recommendations of engineer, business managers, and lawyers of the 18th, 19th, and 20th centuries, conventional accounting has been shaped as a rule-based function designed to create an accounting database for management from which it could speedily and easily extract periodic financial statements.

The body of accounting knowledge is made-up of a mounting "set of arbitrary connected rules uniformed by theoretical argument and 
largely attributed to non-accountants" [12]. Accounting practitioners have developed accounting in response to real-world circumstances [3]. Accounting is a collective body of knowledge that is independent of the relationship between crises and their accounting-based solutions, rendering the accounting discipline nothing more than disproportional responses to economic crises [14]. A rules-based accounting system disqualifies accounting from claiming a status of professionalism [13]. The status quo of accounting as a discipline has also been recently doubted, or even attacked, by some of its own affiliated members $[61,62]$.

Accounting roles "are implicated in action, rather than being prior to it" [5]. An attempt to justify, or may be even rationalize, existing accounting practices-which have not been normatively theorized in advance to reach predetermined ends or outcomes-may be a failed trail. That is, theorizing accounting techniques and procedures prior to putting them into practice may be an opening for others to critique and criticize one's effort as well as for others to credit by challenging presented conjectures and assertions.

Endeavours to abstract accounting methods and practices may not yield a convincing logic. According to Vatter "Accounting is not a purely logical structure" [4]. Economic rationality that might be epitomized within the perceptions and practices of accounting are tentative [5]. Attempts to theorize some accounting practices, for example the historical cost, may be viewed, at best, as an apology of the current accounting practices [63]. Thomas warns that "the problem with theoretical justification is one of defending his choice" [44].

By contrast, I believe that any attempt to understand or challenge practiced accounting through rationalization is a brave struggle and, at the same time, a mind-stimulating activity. It is an effort to further the accountancy profession and expand our understanding in accountancy as a discipline. Bear "in mind that there is little in the development of accounting as practiced that would lead one to describe its essential in terms of furtherance of economic efficiency or rationality" [5].

Efforts to rationalize the accounting practices of historical cost principle, however, affirms that without understanding the nature of a firm, there is no hope in justifying or rationalizing practiced accounting [63]. Several attempts have been made over a century to theorize a firm, which have virtually yielded the same point of departure. In 1897, Davis attempted to understand the nature, formulation, and operation of a corporation. About 50 years later, an accountant writer states, [64]"Despite the impact of the large corporation on society, most social sciences have not developed a conceptual frame of reference, which would serve as a guide to policy and an explanation of corporate behaviour" [65]. Another 50 years later (100 years from 1897), Kornhauser attempted to understand and theorize a corporation as a nexus of contract [66-68]. We have either the legal theory that "is coached in terms of a corporate person" or the economic theory [65]. Views of the firm or theorized corporation that have been proposed thus far are neither revolutionary nor thought evoking [69]. In addition to our efforts to apologize for practiced accounting, I am still unconvinced that we, accountants, have understood the firm and, importantly, rightly theorized it. Accountants perceive "Themselves as the monitors of world economic order" [37]. Rampy trusts that, "every real accountant is a public servant [rendering him-/ her] to accounting data disseminated to the public fairly presents the financial facts of the business or activity involved" [70]. However, accountants have been fundamentally adopting views nurtured in other disciplines $[12,45]$. For example, on the separation between ownership and control, the argument that decision agents who do not share substantial wealth in an organization will lead to the organization's survival [34] is rooted in economic traditions. Some efforts have been made by accounting writers who have a sound comprehension of changes in the corporate economy and its differences from other economies run by sole and partnership types of entities [11]. Proposed accounting valuation based on such efforts, however, may not properly reflect observed reality. In fact, it is more a reflection of the theorists' normative theoretical approach to the corporation as well as whom and how accounting ought to serve. The fact that Paton regretted co-authoring the 1940 monograph exemplifies the imposition based on what an accounting theorist wanted to see as opposed to portray what is observed. Recently, the FASB issued the Statement of Financial Accounting Concept No. 8 (SFAC No. 8), which replaced both SFAC No. 1 and SFAC No. 2. SFAC No. 8 [71-74] substitutes the proprietary theory with an entity view toward a corporation [75,76]. The divorce between ownership and management as well as control necessitates an entity view on the corporation [69]. It corresponds to a legal-economic idea, which makes it the rule rather than the exception [77]. While such an alternation in the adopted theatrical approach toward the corporation can be deemed a type of improvement in accounting, both views are insufficient in visualizing a large corporation [65]. An accounting system that deals with the distinction between shareholders' income and equity from income and equity to the enterprise is a recently proposed and possibly, improved method of corporate reporting [78]. Further studies are warranted to evoke accounting researchers' thoughts to assist in the better understanding of the firm and propose more suitable corporate reporting models or frameworks.

\section{Conclusion}

A firm or corporation, in my opinion, has yet to be well theorized or conceptualized for the purpose of accounting, which serves a society characterized by its members who contribute their wealth to creating giant and multinationals entities but not willing or able to act as responsible owners. "Much of the irrationality of life in modern organizations arises because the organization itself must maintain a national corporate persona..." [5]. In justifying their stewardship, when presenting financial statements to the stockholders, directors of corporations are concerned with finance, taxation, and public relations as well as accounting factors [79]. What is a corporation? Accounting systems have become a fundamental aspect of a firm's structure [69]. Accounting systems in a business entity is an integrating element that combines the implications of economics, accounting, and legal matters within a firm [80]. Accountants must contribute to addressing how a firm should be viewed and then, propose a new role for corporate accounting or adapt to one of the existing roles. The roles of accounting "could emerge at a distance from practice, often shaped by very different institutional contexts and bodies of thought and thereafter serve as bases for changing practice" [5]. The realization of the role of accounting at a given time and place is essential for its development. As such, accounting roles serve as a "normative structure" in identifying errors in accounting practices [5].

In conclusion, I call for the rethinking of corporate accounting by first, profoundly comprehending the idea or the concept of a firm. It takes more than accounting theory to produce financial reports [79]. This paper is not a call to abandon accounting as practiced. Instead of simply trying to rationalize it, we are in need of research on rethinking our role and how to better serve our societies. Without understanding the social context in which accounting roles originated, such roles remain absolute [5]. There also remains a need to theorize and conceptualize a corporation. Although it can be argued that accounting 
practices may best be understood in terms of "accountability" [40], it varies by the presence of a capital provider and his/her awareness of day-to-day transactions and business affairs. Without recognizing the nature of the corporate economy, accounting would be futile. Accounting has been able to change its purpose and this very feature of adaptability has maintained its usefulness as a tool for societies till date.

\section{Acknowledgement}

I am grateful to Dr. Gary J. Previts for the knowledge I acquired as his student of the advanced accounting theory and accounting regulation courses as well as at the lectures on the Development of Accounting Thought in a Doctoral Seminar. In addition to the readings during the courses, which remain valuable to date, he continues to share material and comments with me. It was truly a privilege to have Dr. Previts on my dissertation committee. Dr. Timothy J. Fogarty's comments on some parts of earlier versions of the paper are highly appreciated. Chairing my dissertation committee by $\mathrm{Dr}$. Fogarty was indeed a source of pride.

\section{References}

1. Hopwood AG (1978) Toward an Organizational Perspective for the Study of Accounting and Information Systems. Accounting Organizations and Society 3: 3-13.

2. McCredie $H$ (1957) The Theory and Practice of Accounting. The Accounting Review 32: 216-223

3. Chambers RJ (1960) The Conditions of Research and Accounting. Journal of Accountancy, June: 33-38.

4. Vatter WJ (1963) Postulates and Principles. Journal of Accounting Research 1: 179-197.

5. Burchell S, Clubb C, Hopwood A, Hughes J, Nahapiet J (1980) The Roles of Accounting in Organizations and Society. Accounting, Organizations and Society 5: 5-27.

6. Mumford MJ (1993) Users, Characteristics and Standards. In: Mumford MJ, Peasnell KV editiors. Philosophical Perspectives on Accounting: Essays in Honors of Edward Stamp. Routledge, London, pp: 7-29.

7. Al-Adeem K (2015) Sustaining Mutual and Market Interests in the Auditor and Corporate Client Relationship. American Accounting Association Mid-Atlantic Region Meeting. April 23-25, Cherry Hill, NJ.

8. Tony Jackson Trying to Serve Two Masters: The Stakeholder-Shareholde Debate is no closer to Being Reconciled. Financial Times 22 December: 10.

9. Bricker RJ, Previts GJ (1992) Changing the Orientation of Financial Reporting: An Information Rights Perspective. A Proceeding Presented at the 1991 National Annual Meeting of the American Accounting Association.

10. Sanders TH, Hatfield HR, Moore U (1938) A Statement of Accounting Principles. American Institute of Accountants (AIA), New York, USA.

11. Paton A, Littleton AC (1940) An Introduction to Corporate Accounting Standards. American Accounting Association.

12. Lee TA, Wolnizer PW (2012) An Intellectual Memorial to Robert Raymond Sterling, Accounting Reformer. Accounting Horizons 26: 135-146.

13. West BP (2003) Professionalism and Accounting Rules. Routledge, New York.

14. Waymire G, Basu S (2007) Accounting is an Evolved Economic Institution. Now Publishing Inc. Hanover, MA.

15. Jones $T$ (1857) Bookkeeping and Accountantship, Elementary and Practical. John Wiley \& Sons Inc, New York, USA.

16. Lee TA (2009) Financial Accounting Theory. In: Edwards JR, Walker SP editors. The Routledge Companion to Accounting Theory. Taylor \& Francis Group, Routledge, London, pp: 139-161.

17. Kieso DE, Weygandt JJ, Warfield TD (2004) Intermediate Accounting (11 $1^{\text {th }}$ edn.), John Wiley \& Sons Inc, New York, USA.

18. Gjesdal F (1981) Accounting for stewardship. Journal of Accounting Research 19: $208-231$

19. Yamey BS (1947) Notes on the Origin of Double-Entry Bookkeeping. The Accounting Review 22: 263-272.

20. Gleeson-White J (2011) Double Entry: How the Merchants of Venice shaped the Modern World-and How their Invention Could Make or Break the Planet. Allen \& Unwin, Crows Nest, New South Wales.

21. Hackett W, Mobley S (1976) An Auditing Perspective of the Historical Development of Internal Control. Auditing Symposium III: Proceedings of the 1976 Touche Ross/University of Kansas Symposium on Auditing Problems, Lawrence, Kansas: University of Kansas.

22. Chatfieild M (1977) A History of Accounting Thought. Robert E. Krieger Publishing Company, New York, USA

23. Littleton AC (1958) Accounting Rediscovered. The Accounting Review 33: 246-253.

24. Littleton AC (1966) Accounting Evolution to 1900. Russell and Russell, New York.

25. Anderson JA (1977) The Potential Impact of Knowledge of Market Efficiency on the Legal Liability of Auditors. The Accounting Review 52: 417-426.

26. Wyhe GV (1994) The Struggle for Status. Garland Publishing, Inc., New York, USA.

27. Lazonik W (1988) Financial Commitment and Economic Performance: Ownership and Control in the American Industrial Corporation. Business and Economic History, Second Series. 17: 115-128.

28. Hendriksen ES, Breda M (2001) Accounting Theory. Irwin Professional Publishing, Illinois.

29. Baskin JB, Miranti PJ Jr (1997) A History of Corporate Finance. Cambridge University Press, Cambridge, United Kingdom.

30. Chambers RJ, Wolnizer PW (1991) A True and Fair View of Position and Results: The Historical Background. Accounting Business and Financia History 1: 197-213

31. Littleton AC (1928) Paciolo and Modern Accounting. The Accounting Review 3: 131-140.

32. Armstrong K (2002) Islam: A Short History. The Modern Library, New York.

33. Previts GJ, Merino BD (1998) A History of Accountancy in the United States. State University Press, Columbus, Ohio.

34. Fama EF and Jensen MC (1983) Separation of Ownership and Control The Journal of Law and Economics, Corporations and Private Property: A Conference Sponsored by Hoover Institution. 26: 301-325.

35. Drucker APA (1928) The Accountant as an Efficiency Expert. The Accounting Review 3: 364-368.

36. Littleton AC (1958). Accounting Rediscovered. The Accounting Review 33 246-253.

37. Montagna P (1986) Accounting Rationality and Financial Legitimation. Theory and Society 15: 103-138.

38. Jeter D, Chaney P (2001) Advanced Accounting (1st edn.), John Wiley \& Sons Inc, New York, USA.

39. Cooper R (1989) Big Mergers Will Cause Some Areas Shake-up. Business First 6: 1.

40. Statement on Accounting Theory and Theory Acceptance (SATTA) (1977) Committee on Concepts and Standards for Externals Financial Reports. American Accounting Association, Sarasota, Florida.

41. A Statement of Objectives of the American Accounting Association (1936) The Accounting Review 11: 1-4.

42. Berle AA, Means GC (1932) The Modern Corporation and Private Property Macmillan, New York, USA

43. Merino BD (1993) An Analysis of the Development of Accounting Knowledge: A Pragmatic Approach. Accounting Organizations and Society 18: 163-185.

44. Brearey $\mathrm{CH}, \mathrm{Al}-\mathrm{Adeem} \mathrm{KR}$ (2006) Thinking Beyond the Black Box: Sterling as an Economist Shows Accountants the Way toward Relevance. A Proceeding Presented at the Ohio Regional Meeting, American Accounting Association, May 4-6. Cleveland, Ohio.

45. Thomas AL (1974) The Allocation Problem in Financial Accounting Theory American Accounting Association.

46. Hamid [Alhomaid], Ibrahim ARB (2009) accounting theory. Library Al Obaikan Riyadh, Kingdom of Saudi Arabia. 
Citation: Al-Adeem KR (2017) A Need for Theorizing Corporation: An Accounting Perspective. Int J Account Res 5: 166. doi:10.4172/2472114X.1000166

47. Belkaoui AR (2004) Accounting Theory ( $5^{\text {th }}$ edn.), Thomson Learning, London.

48. Zeff SA (2005) The Evolution of U.S. GAAP: The Political Forces Behind Professional Standards: Part 1. The CPA Journal 75:18-27.

49. Recognition and Measurement in Financial Statements of Business Enterprises (Concepts Statement No. 5) (1984) Financial Accounting Standards Board, pp 1-27.

50. Zeff SA (1999) The Evolution of the Conceptual Framework for Business Enterprises in the United States. The Accounting Historians Journal 26: 89-131.

51. Sterling RR (2003) A patch on GAAP Abacus. 39: I-VI.

52. Kohler EL (1963) Why Not Retains Historical Cost? Journal of Accountancy. 35-41.

53. Conner D (1992) Managing at the Speed of Change: How Resilient Managers Succeed and Prosper where Others Fail. Random House, New York, USA.

54. Davis HZ (1997) History of LIFO. In: Edward N editor. Coffman, Rasoul H. Tondkar and Gary John Previts (2nd edn.), Historical Perspectives of Selected Financial Accounting Topics. The McGraw-Hill Companies, New York, USA.

55. Al-Hogail AA, Previts GJ (2001) Raymond J Chambers' Contributions to the Development of Accounting Thought. The Accounting Historians Journal 1-30.

56. Nusbaum E, Weiss J (1993) AICPA/Special Committee on Financial Reporting Journal of Corporate Accounting \& Finance, 5: 289-292.

57. Improving Business Reporting-A Customer Focus (1994) Special Committee on Financial Reporting.

58. DR Scott (1926) Conservatism in Inventory Valuations. Papers and Proceedings of Tenth Annual Meeting of the American Accounting Association of University Instructors of Accounting. The Accounting Review 1:18-30.

59. White GI, Sondhi AA, Fried D (2003) The Analysis and the Use of Financial Statements ( $3^{\text {rd }}$ edition). John Wiley \& Sons Inc, Hoboken.

60. Chambers RJ (1957) Detail for a Blueprint. The Accounting Review 32: 206215.

61. Demski JS (2007) Is Accounting an Academic Discipline? Accounting Horizons 21: 153-157.

62. Fellingham JC (2007) Is Accounting an Academic Discipline? Accounting Horizons, 21: 159-163.

63. Braun E (2016) The Ecological Rationality of Historical Costs and Conservatism Accounting, Economics and Law 6: 1-30

64. Davis JP (1897) The Nature of Corporations. Political Science Quarterly 12 273-294.
65. Suajanen WW (1954) Accounting Theory and the Large Corporation. The Accounting Review, 29: 391-398.

66. Kornhauser LA (1989) The Nexus of Contracts Approach to Corporations: A Comment on Easterbrook and Fischel Contractual Freedom in Corporate Law Columbia Law Review Association, Inc 89: 1449-1460.

67. Eisenberg MA (1998) The Conception That the Corporation Is a Nexus of Contracts, and the Dual Nature of the Firm, Journal of Corporation Law.

68. Hayden GM, Bodie MT, Ribstein LE (2011) The Uncorporation and the Unravelling of 'Nexus of Contracts' Theory Michigan Law Review 109: 11271144.

69. Biondi Y (2005) The Firm as an Entity: Management, Organization, Accounting University of Brescia.

70. Rampy TR (1952) The Accountant's Role in our Present Economy. The Accounting Review 27: 467-471.

71. Paton W (1971) Introduction. In: WE Stone. Foundation of Accounting Theory Conference Proceeding on Foundation of Accounting 1970. University of Florida Press, Gaiesville.

72. Objectives of Financial Reporting by Business Enterprises (Concepts Statement No. 1) (1978) Financial Accounting Standards Board, pp 1-17.

73. Qualitative Characteristics of Accounting Information (Concepts Statement No. 2) (1980) Financial Accounting Standards Board, pp 1-37.

74. Conceptual Framework for Financial Reporting-Chapter 1, The Objective of General Purpose Financial Reporting, and Chapter 3, Qualitative Characteristics of Useful (Concepts Statement No.8) Financial Information Financial Accounting Standards Board (2010)

75. Previts GJ, Flesher DL (2015) Financial Accounting and Reporting in the United States of America 1820-2010. In: Stewart Jones editor. The Routledge Companion to Financial Accounting Theory 39.

76. Schroeder RG, Clark MW, Cathey JM (2010) Financial Accounting Theory and Analysis (10th edn.), John Wiley \& Sons Inc., New York, USA.

77. Biondi $Y$ (2011) The enterprise Entity and the Constitution of the American Economic Republic. Accounting, Economics and Law 1: 1-13.

78. Biondi Y (2012) What Do Shareholders Do? Accounting, Ownership and the Theory of the Firm: Implications for Corporate Governance and Reporting. Accounting, Economics and Law 2: 1-27.

79. Cowan TK (1965) Are truth and Fairness Generally Acceptable? The Accounting Review 40: 788-794.

80. Biondi $Y$ (2009) Governing the Business Enterprise: Ownership, Institutions Society. CLPE 5: 1-6. 